\title{
KINERJA PEMBANGUNAN KESATUAN PENGELOLAAN HUTAN LINDUNG SUNGAI WAIN DAN DAS MANGGAR DI PROVINSI KALIMANTAN TIMUR
}

\author{
Performance Of Development Of Protection Forest Management Unit Wain And \\ Manggar River In East Kalimantan Province
}

\section{Andi Chairil Ichsan}

Program Studi Kehutanan Universitas Mataram

JI Majapahit No 62, Mataram, NTB

Email ; andi.foresta@unram.ac.id

\begin{abstract}
The purpose of this study was to assess the performance of KPHL Sungai Wain and DAS manggar (SWDM) in carrying out forest management at site level using criteria and indicators from Forest Watch Indonesia version 1.0. The results show that the overall average of the criteria being assessed is an insufficient range, which means that the SWDM KPHL is good enough to perform its function as a forest management unit at the site level. However, after the implementation of Law 23 of 2014, HLSWDM management institutions have uncertainty due to lack of coordination between the parties in following up the policy change. Thus, it takes an approach oriented to the four main dimensions, namely; external environmental conditions, institutional motivation, capacity and institutional performance.
\end{abstract}

Keywords: Performance , Management, Forest, Protection

\begin{abstract}
Abstrak
Tujuan penelitian ini adalah untuk menilai kinerja KPHL Sungai Wain dan DAS manggar (SWDM) dalam menjalankan pengelolaan hutan di tingkat tapak dengan menggunakan kriteria dan indikator dari Forest Watch Indonesia versi 1.0. Hasilnya menunjukkan bahwa rata-rata keseluruhan kriteria yang dinilai berada pada rentang cukup, yang berarti KPHL SWDM cukup baik dalam menjalankan fungsinya sebagai unit pengelola hutan di tingkat tapak. Namun demikian, pasca penerapan UU 23 tahun 2014, kelembagaan pengelolaan HLSWDM mengalami ketidakpastian akibat kurangnya koordinasi antar pihak dalam menindak lanjuti perubahan kebijakan tersebut. Dengan demikian, dibutuhkan sebuah pendekatan yang berorientasi pada empat dimensi utama, yaitu; kondisi lingkungan eksternal, motivasi kelembagaan, serta kapasitas dan kinerja kelembagaan yang dijalankan.
\end{abstract}

Kata kunci: Kinerja, Pengelolaan, Hutan, Lindung

\section{Pendahuluan}

Tingginya laju deforestasi sumberdaya hutan di indonesia tidak lepas dari lemahnya tatakelola hutan di tingkat tapak (GFI 2013, UNDP 2013). Forest Watch Indonesia menyebutkan bahwa laju deforestasi periode 2009 - 2013 mencapai rata-rata 1,13 juta ha per tahun, dimana tutupan hutan tersisa tahun 2013 seluas 82 juta ha (FWI, 2014). Disisi lain, Wiyono et al, (2006) menyatakan bahwa sekitar 48,8 juta penduduk 
Indonesia bertempat tinggal di dalam dan sekitar kawasan hutan, dan sekitar 10,2 juta jiwa di antaranya tergolong dalam klasifikasi miskin, dimana pada umumnya mata pencaharian masyarakat tersebut adalah memanfaatkan produk-produk hutan, baik kayu maupun bukan kayu, antara lain rotan, damar, gaharu dan pemanfaatan lebah madu oleh masyarakat sekitar hutan.

Situasi tersebut juga terjadi pada wilayah kesatuan pengelolaan hutan lindung (KPHL) Sungai Wain - Sungai Manggar (HLSWDM) yang terletak di Kota Balikpapan Provinsi Kalimantan Timur. Secara umum kegiatan penebangan liar dan pengumpulan gaharu di dalam kawasan HLSW selalu diikuti dengan kegiatan perburuan satwa liar. Perburuan satwa liar yang dilindungi dilakukan oleh para pencari kayu baik dimanfaatkan untuk bahan pangan bahkan tidak jarang binatang tangkapan tersebut diawetkan atau dijual. Disisi lain, maraknya perambahan yang terjadi disekitar wilayah tersebut turut andil pada menyusutnya kualitas maupun kuantitas sumberdaya hutan di wilayah HLSW-DM ini (RTHRP-HLSW 2015)

Menyikapi berbagai persoalan yang muncul dalam pengelolaan sumberdaya hutan, pemerintah melalui badan lingkungan hidup kota Balikpapan membentuk tim multipihak yang berfungsi untuk mengawal pelaksanaan pengelolaan hutan ditingkat tapak, baik dari aspek perencanaan sampai pada proses evaluasinya. Secara de fakto tim ini merupakan manivestasi dari pengembangan kesatuan pengelolaan hutan yang saat ini dikembangkan oleh kementerian kehutanan republik indonesia. Secara konseptual kebijakan pembangunan $\mathrm{KPH}$ merupakan proses pergeseran institusi yang membawa perubahan fundamental pada cara berfikir, sistem nilai dan budaya pengurusan hutan Indonesia. Peran $\mathrm{KPH}$ akan menggeser titik tumpu peran birokrat kehutanan dari forest administrator menjadi forest manager, serta meningkatkan transparansi dan akuntabilitas tata kelola hutan (Kartodihardjo, Suwarno 2014)

Secara berjenjang sampai tahun 2019 direncanakan akan terbentuk $600 \mathrm{KPH}$ diseluruh wilayah Indonesia, termasuk didalamnya adalah KPHL Unit XXX (Hutan Lindung Sungai Wain dan Sungai Manggar) yang terletak pada posisi antara $1^{\circ} 2^{\prime} 38,08^{\prime \prime}$

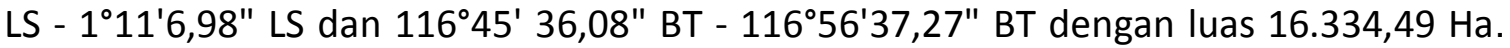
Pentepan Wilayah KPH tersebut diatur melalui Keputusan Menteri Kehutanan Nomor : SK. 674/Menhut-II/2011 Tentang Penetapan Wilayah Kesatuan Pengelolaan Hutan Lindung (KPHL) dan Kesatuan Pengelolaan Hutan Produksi (KPHP) di Provinsi Kalimantan Timur.

Keberadaan Institusi pengelolaan hutan yang berbasis pada pendeketan multisektor merupakan ciri spesifik yang dimiliki BPHLSWDM, sehingga proses pengelolaan yang dijalankanpun memiliki karakteristik yang khas dan berbeda dari sistem pengelolaan KPH yang dijalankan pada umumnya. Dengan demikian, tujuan kajian ini diarahkan untuk memberikan gambaran terkait kinerja pengelolaan hutan yang dijalankan oleh BPHLSDM dengan menggunakan parameter yang tertuang dalam kriteria dan indikator FWI 1.0.

\section{Metode}

Penelitian dilaksanakan pada bulan Februari-April 2017 di wilayah pengelolaan hutan lindung sungai Wain dan sungai Manggar (HLSW-DM). Metode yang digunakan adalah metode deskriptif yang bertujuan untuk mengumpulkan informasi yang ada pada saat sekarang, menganalisisnya dan menginterpretasikan fakta atau informasi yang ditemukan (Narbuko, 2003). 


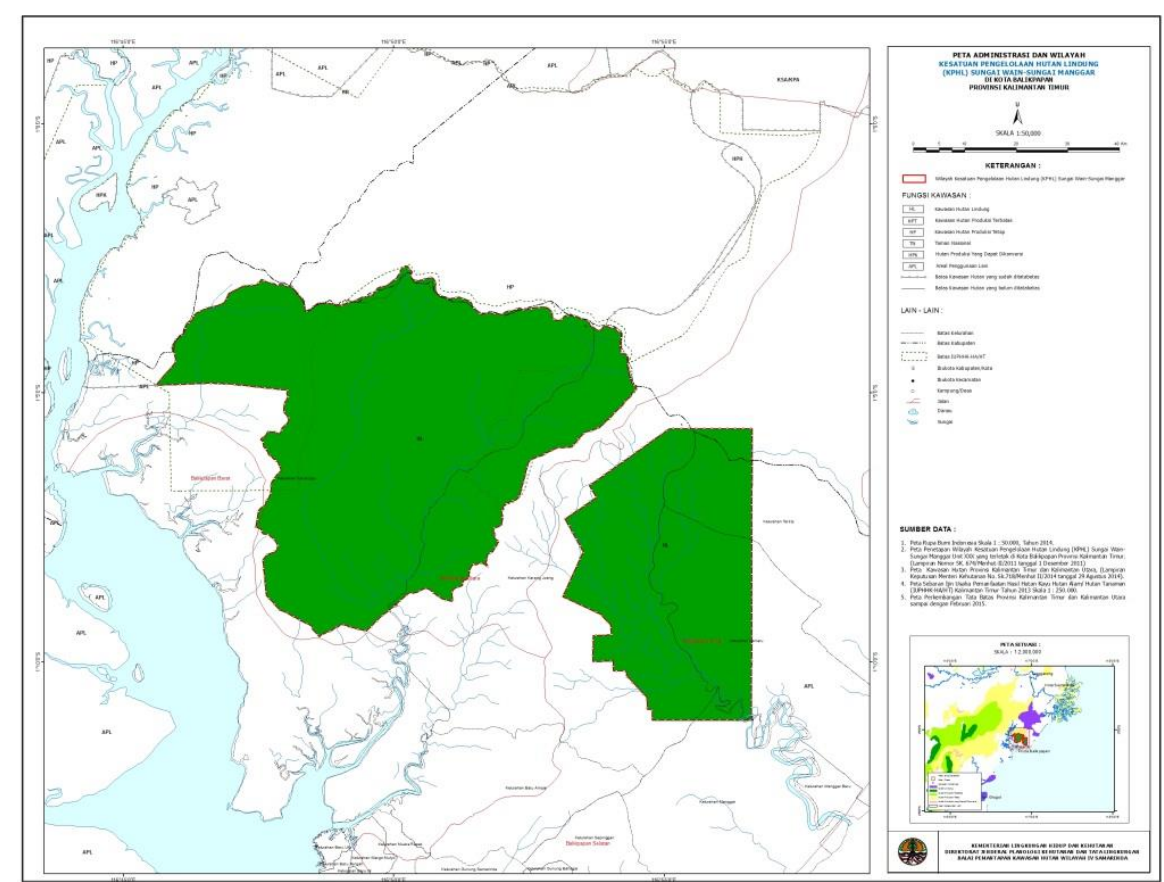

Gambar 1. Peta Wilayah KPHL HLSW

Figure 1. Map of KPHL HLSW

Data yang terkumpul kemudian diolah menggunakan kriteria dan indikator Forest Watch Indonesia versi 1.0 (Forest Watch Indonesia, 2014). Hasilnya disajikan dalam bentuk indeks, dengan menghitung jumlah nilai seluruh unit data kemudian dibagi banyaknya unit data. Indeks Penilaian Kinerja Pembangunan KPH dapat dikategorikan menjadi tiga kelas yaitu tinggi, sedang dan rendah (Tabel 1).

Indeks penilaian Kinerja Pembangunan KPH dapat dikategorikan menjadi tiga kelas yaitu Tinggi, Sedang dan Rendah dengan penjelasan sebagai berikut :

Tabel 1. Kategorisasi Indeks Penilaian Kinerja Pembangunan KPH Table 1. Categorization of KPH Development Performance Assessment Index

\begin{tabular}{ccl} 
Nilai Indeks & Kategori & Uraian \\
\hline $2,34-3,00$ & Tinggi & $\begin{array}{l}\text { Merupakan nilai rata-rata ideal yang diperoleh dari setiap } \\
\text { elemen kualitas, indikator maupun kriteria. }\end{array}$ \\
\hline $1,67-2,33$ & Sedang & $\begin{array}{l}\text { Merupakan nilai rata-rata kategori sedang yang diperoleh } \\
\text { dari setiap elemen kualitas, indikator maupun kriteria. }\end{array}$ \\
\hline $1,00-1,66$ & Rendah & $\begin{array}{l}\text { Merupakan nilai rata-rata rendah yang diperoleh dari } \\
\text { setiap elemen kualitas, indikator maupun kriteria. }\end{array}$
\end{tabular}

Indeks diatas diolah dari skor setiap elemen kualitas yang mempunyai gradasi dari nilai tertinggi sampai terendah, dengan pertimbangan bahwa setiap bobot dalam elemen kualitas dan indikator adalah setara. 
Tabel 2. Kategorisasi Bobot Penilaian Kinerja Pembangunan KPH

Table 2. Categorization of Weighted Assessment of KPH Development Performance

\section{Uraian}

Skor

Bila data lapangan memenuhi seluruh unsur yang tertuang dalam elemen kualiitas

Bila data lapangan hanya memenuhi sebagian unsur yang tertuang dalam elemen kualiitas

Bila data lapangan tidak memenuhi seluruh unsur yang tertuang dalam elemen kualiitas

\section{Catatan : Skor penilaian merupakan pilihan keputusan yang didasarkan pada hasil temuan yang telah dianalisis dan diverifikasi.}

Tahapan pengelolaan data terdiri dari tabulasi data dan analisis data berdasarkan temuan lapangan. Komponen Kriteria dan Indikator dalam penilaian ini didasarkan pada kerangka matriks kriteria dan indikator yang sudah dibangun sebelumnya oleh tim ahli ${ }^{1}$ bekerjasama dengan Forest Watch Indonesia. Matriks penilaian ini terdiri dari 8 kriteria, 22 indikator dan 49 elemen kualitas.

\section{Hasil dan Pembahasan}

Hasil penilaian yang dilakukan dengan menggunakan panduan penilaian kinerja pembangunan KPH FWI 1.0, menunjukan bahwa dari 8 kriteria yang dinilai, rata-rata keseluruhan kriteria berada pada rentang cukup baik. Hal ini berarti KPH HLSWDM cukup baik dalam konteks kelembagaan maupun operasionalisasi pengelolaan hutannya di tingkat tapak. Namun demikan ada beberapa kriteria yang masih perlu diperkuat seperti mekanisme investasi dan kriteria rencana pengelolaan seperti yang tergambar pada gambar 2 dibawah ini.

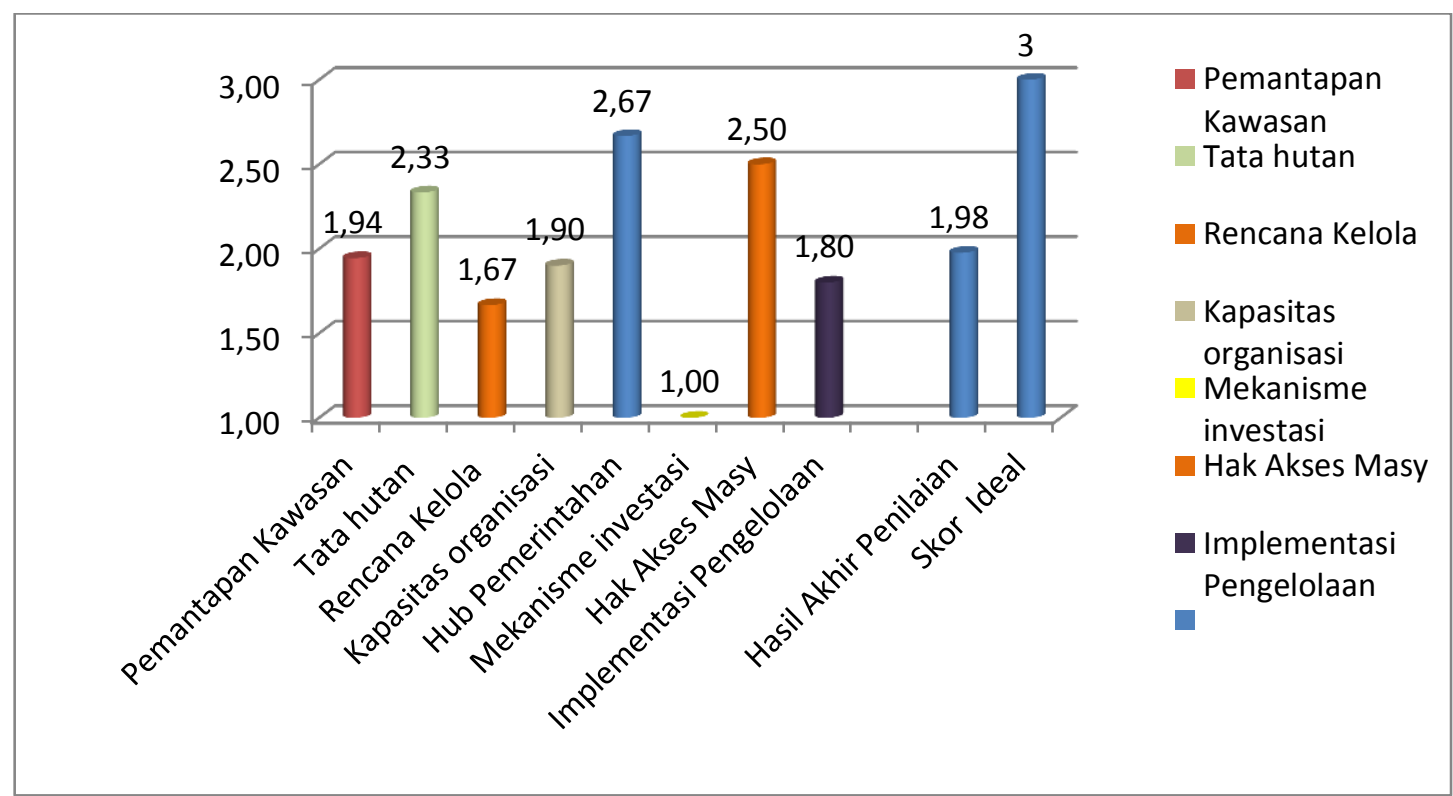

Gambar 2. Matriks hasil penilaian kinerja pembangunan KPHL SWDM

Figure 2. Matrix of performance assessment result of KPHL HLSWDM

\footnotetext{
${ }^{1}$ Komposisi tim ahli : Hariadi Kartodihardjo (Guru Besar Fakultas Kehutanan IPB), Hariyanto R. Putro (Dosen Fakultas Kehutanan IPB) dan Eno Suwarno (Dosen Fakultas Kehutanan Universitas Lancang Kuning)
} 
Dari gambar diatas, dapat diuraikan bahwa pengelolaan HLSWDM masih cukup lemah dari aspek investasi. Hasil penilaian menunjukaan bahwa selama ini pengelolaan HLSWDM masih terfokus pada upaya penataan internal kelembagaan dan tatakelola kawasan. Belum tersedia infrastruktur dan mekanisme yang memberikan ruang investasi yang memadai bagi sektor lain untuk mengembangkan usahanya di kawasan HLSWDM. $\mathrm{Hal}$ ini terlihat dari belum adanya struktur yang disediakan untuk memfsilitasi kepentingan investasi dalam pengelolaan hutan di tingkat tapak.

Disisi lain, berdasarkan parameter yang dikembangkan dalam kriteria dan indikator FWI 1.0, terdapat beberapa aspek strategis yang perlu menjadi fokus perhatian serius dari pengelola untuk mengoptimalkan pengelolaan yang dijalankan. Beberapa aspek tersebut meliputi :

\section{A. Kepastian kawasan}

Syarat beroperasinya suatu KPH adalah adanya kepastian wilayah pengelolaan. Khusus untuk wilayah HLSW dan DAS Manggar, proses tatabatas luar kawasan sudah pernah dilakukan berdasarkan BATB yang dibuat pada tahun 1993 dan 1995 oleh BPKH dan instansi teknis lainnya.

Berdasarkan hasil analisis yang dilakukan, diperoleh informasi bahwa KPHL Unit XXX Sungai Wain dan DAS Manggar terbagi atas dua wilayah yaitu Hutan Lindung Sungai Wain dan Hutan Lindung DAS Manggar. Kedua kawasan hutan lindung tersebut memiliki karakteristik yang berbeda baik dari aspek ekologi maupun sosial budayanya, sehingga dalam proses penilaian perlu mempertimbangkan kedua wilayah ini sebagai dua wilayah berbeda dalam satu kesatuan pengelolaan KPHL.

Terkait dengan aspek kepastian wilayah, terdapat beberapa temuan penting yang dapat diuraikan sebagai dasar untuk pengembangan program di lapangan, temuan tersebut yaitu :

1. Sejak ditetapkan pada tahun 2004 , proses rekonstruksi tatabatas belum pernah dilakukan. Padahal, sesuai intruksi SK Direktur Jenderal Inventarisasi Dan Tata Guna Hutan No. 12/Kpts/VII-1/1992 memberikan mandat agar proses rekonstruksi tatabatas dilakukan 5 tahun sekali untuk memberikan kepastian wilayah pengelolaan sumberdaya hutan.

2. Dalam proses tatabatas yang dilakukan oleh instansi yang berwenang (Balai Pemantapan Kawasan Hutan) tidak melibatkan masyarakat yang berada di sekitar lokasi, sehingga menimbulkan ekses di masyarakat berupa konflik tenurial (Kasus Wilayah DAS Manggar) yang sampai saat ini masih berlangsung . Hal ini juga mencederai mandat pasal 68 UU No 41 Tahun 1999 yang dengan tegas memberikan mandat bahwa masyarakat berhak mengawasi pembangunan kehutanan mulai dari perencanaan sampai pada tahap evaluasinya.

3. Masyarakat yang berada di sekitar kawasan tidak mengetahui proses penataan batas yang sudah dilakukan, selama ini juga tidak ada sosialisasi oleh instansi yang berwenang tersebut kepada masyarakat.

4. Anggaran untuk tata batas tidak dianggarkan oleh BPHLSW-DM karena dianggap bahwa pelaksanaan tatabatas bukan merupakan tugas pokok BPHLSW-DM melainkan tugas pokok BPKH. Namun berdasarkan pernyataan $\mathrm{BPKH}$ saat ini tidak ada anggaran khusus terkait rekosntruksi tata batas. BPKH mengharapkan agar $\mathrm{KPH}-\mathrm{KPH}$ dapat menganggarkan kegiatan rekonstruksi tata batas melalui APBD. 


\section{B. Kelembagaan}

Dari perspektif kelembagaan, selama ini Kawasan Hutan Lindung Sungai Wain dan DAS Manggar dikelola oleh Badan Pengelola Hutan Lindung Sungai Wain dan DAS Manggar (BPHLSW-DM) sebagai tim adhok berdasarkan PERDA Balikpapan No 11 tahun 2004 tentang pengelolaan HLSW. Badan ini adalah sebuah platform multistakeholder yang keanggotaannya terdiri dari berbagai sektor baik pemerintahan, swasta, masyarakat dan LSM pendamping yang tergabung dalam Badan Pengelola Hutan Lindung Sungai Wain dan DAS Manggar (BPHLSW-DM). Saat ini BPHLSW-DM diketuai oleh Bapak Purwanto, S.Hut dan dibantu oleh beberapa perwakilan masyarakat. Selama pengelolaan dengan pola tim adhok ini cukup banyak dinamika dan tantangan yang dihadapi oleh badan pengurus, beberapa di antaranya, yaitu :

1. BPHLSW sebagai tim adhok tidak mempunyai kewenangan untuk mengatur, mengontrol dan mengendalikan para pemegang izin yang terdapat di wilayah HLSW dan DAS Manggar, karena secara institusi bukan merupakan instansi pemerintahan yang diberikan kewenangan untuk hal tersebut, seperti tugas yang diberikan kepada KPH sesuai mandat PP No 6 Tahun 2007 Jo PP No 3 Tahun 2008.

2. Sejak pembentukan wilayah KPHL Unit XXX HLSW dan DAS manggar, secara tidak langsung banyak instansi yang menyamakan fungsi dan peran BPHLSWDM sebagai $\mathrm{KPH}$. Hal ini dapat dilihat dari tidak diindahkannya surat edaran gubernur tahun 2011 tentang pembentukan struktur KPH kepada kabupaten kota se-Kalimantan Timur sesuai dengan arahan Permendagri No 61 Tahun 2010, karena menganggap BPHLSW-DM sudah merupakan manivestasi KPH di Balikpapan. BPHLSW-DM juga sering menerima undangan untuk mewakili lembaga pengelola KPHL dan adanya distribusi tenaga bakti rimbawan yang diperbantukan oleh KLHK untuk mengawal operaisonalisasi pengelolaan wilayah KPHL Unit XXX.

3. Untuk operasionalisasi BPHLSW-DM, Pemerintah Kota Balikpapan menyediakan anggaran berupa dana hibah yang dikucurkan setiap tahun sebesar 4 sampai 6 milyar. Namun demikian skema dana ini masih bersifat dana hibah dan tidak termasuk dana rutin sebagaimana instansi pemerintahan lainnya, sehingga sangat rentan untuk berubah sesuai dengan dinamika dan kondisi di pemerintahan. Terlebih pasca diberlakukannya UU 23/2014, dikhawatirkan akan mengakibatkan terjadinya kekosongan penganggaran operasional pada tahun 2017 setelah Pemerintah Kota Balikpapan tidak memiliki kewenangan atas pengelolaan hutan dan penganggarannya.

4. Terdapat sejumlah staff yang memiliki kemampuan untuk melaksanakan kegiatan-kegiatan tertentu seperti pengamanan, pemberdayaan, resolusi konflik dan pengembangan masyarakat namun jumlahnya masih terbatas dan statusnya masih sebagai tenaga kontrak (Non PNS). Meskipun demikian banyak permasalahan dalam perlindungan dan pengamanan hutan dapat diselesaikan seperti proses terbentuknya HKm di HLSW serta proses negosiasi perhutanan sosial di DAS Manggar.

5. Dalam pengelolaan HLSW selama ini belum terdapat mekanisme yang terstruktur dan sistematis (SOP) terkait dengan beberapa hal seperti proses pelayanan informasi, Pelayanan investasi, proses penyelesaian sengketa bidang kehutanan, resolusi konflik dan pengambilan keputusan. Setiap aktifitas-aktifitas tersebut masih dijalankan dengan mekanisme yang tidak tertulis dan berdasarkan instruksi lisan dari pengelola.

6. Belum terdapat sistem informasi yang lengkap dan up to date terkait dengan pengelolaan HLSW-DM sehingga masih sangat sulit untuk memperoleh informasi yang komprehensif dari satu sumber. Banyak data dan informasi tersebar pada instansi-instansi terkait dengan wilayah HLSWDM seperti unit pelaksana teknis kementerian dan pihak universitas yang berada diwilayah tersebut. Namun 
demikian, BPHLSW-DM secara terbuka memberikan informasi seluas-luasnya kepada pihak mana pun jika diperlukan.

Sejak diimpementasikannya UU No 23 tahun 2014, pengelolaan Hutan Lindung Sungai Wain semakin menemui ketidakpastian, proses transformasi BPHLSW-DM menuju KPH tidak berjalan mulus. Hal ini dapat dilihat dari tidak adanya alokasi anggaran yang disediakan pemerintah Kota Balikpapan untuk melanjutkan operasionalisasi BPHLSW-DM di tahun 2017, karena menganggap kewenangan pengelolaan hutan lindung sudah merupakan otoritas pemerintah provinsi. Namun demikian pemerintah provinsi juga belum menyediakan anggaran operasionalisasi untuk BPHLSW-DM di tahun 2017 karena secara institusi KPHL sendiri belum ada dan akan dirancang kembali bersamaan dengan $34 \mathrm{KPH}$ lainnya di Kalimantan Timur. Dengan demikian hal ini menimbulkan kesimpangsiuran pengelolaan di tingkat tapak terkait dengan operasionalisasi pengelolaan kawasan, dan kepastian nasib sekitar 120 orang staf BPHLSW-DM.

\section{Perencanaan}

Sejak ditetapkan sebagai wilayah $\mathrm{KPH}$, dokumen perencanaan yang disusun harus mengikuti prosedur dan kaidah yang ditentukan dalam Peraturan Direktur Jenderal Planologi Kehutanan Nomor: P.5/VII-WP3H/2012. Merujuk pada konteks tersebut, terdapat beberapa hal penting yang harus segera di tindak lanjuti dan disempurnakan oleh pengelola seperti:

1. Percepatan proses legalisasi dokumen perencanaan yang sudah disusun. Dalam prakteknya, BPHLSW-DM sudah menyusun dokumen rencana pengelolaan yang difasilitasi oleh BPKH dan dokumen tersebut sudah dalam tahap penilaian oleh pihak pusat. Namun demikian, adanya perubahan struktur pengelolaan HLSWDM dari BPHLSW menjadi unit KPH definitif sebagai akibat dari implementasi UU 23 tahun 2014, berakibat pada adanya penyesuaian-penyesuaian terhadap dokumen perencanaan yang sebelumnya telah disusun.

2. Disisi lain, terdapat pengelolaan kawasan yang berpotensi sebagai pusat pengembangan bisnis, yaitu KWPLH, pemanfaatan kawasan Waduk Wain, dan Waduk manggar. Namun demikian, KPHL Unit XXX belum memiliki rencana bisnis sebagai salah satu penunjang untuk mendorong upaya kemandirian $\mathrm{KPH}$.

\section{Alternatif Pilihan Tindakan}

Temuan temuan yang diuraikan diatas, memberikan gambaran bahwa masih banyak aspek aspek penting yang harus dikuatkan dan diperhatikan dalam mengoptimalkan pengelolaan hutan di tingkat tapak, termasuk yang paling krusial yaitu mengenai kepastian pengelolaan pasca penerapan UU 23 tahun 2014. Adiwibowo et al. (2013) mengungkapkan bahwa masalah kritis dalam merancang sebuah kelembagaan, termasuk kelembagaan $\mathrm{KPH}$, adalah isu keberlanjutan kelembagaan itu sendiri. Rancangan kelembagaan seringkali tidak menjadi aturan yang dijalankan oleh para pihak dalam berinteraksi. Semestinya, pengelolaan KPHL SWDM harus dilakukan dengan berorientasi pada pendekatan ekosistem secara utuh dengan mempertimbangkan aspek keberlanjutan dalam pengelolaannya.

Kompleksitas permasalahan pengembangan KPHL SWDM di tingkat tapak tidak lepas dari persoalan kelembagaan yang berfungsi untuk memberikan pengaturan terkait interdependensi antar pemangku kepentingan dalam pelaksanaan pengelolaan $\mathrm{KPH}$. Ada empat dimensi yang perlu didalami dalam mengembangkan suatu kelembagaan termasuk kelembagaan KPH (Mackay, 1998) yaitu :

Satu, kondisi lingkungan eksternal (the external environment). Lingkungan sosial 
di mana suatu kelembagaan hidup merupakan faktor berpengaruh yang dapat menjadi pendorong dan sekaligus pembatas seberapa jauh kelembagaan ini dapat beroperasi. Lingkungan dimaksud berupa kondisi politik dan pemerintahan (administrative and external policies environment), sosiolkultural (sociocultural environment), teknologi (technological environment), kondisi perekonomian (economic environment), berbagai kelompok kepentingan (stakeholders), infrastruktur, serta kebijakan terhadap pengelolaan sumberdaya alam (policy natural resources environment). Seluruh komponen lingkungan tersebut perlu ditelaah bentuk pengaruhnya terhadap kelembagaan $\mathrm{KPH}$ yang akan dikembangkan.

Kedua, motivasi kelembagaan (institutional motivation). Kelembagaan dipandang sebagai suatu unit kajian yang memiliki jiwanya sendiri. terdapat empat aspek yang bisa dianalisis untuk mengetahui motivasi kelembagaan termasuk kelembagaan $\mathrm{KPH}$, yaitu sejarah kelembagaan (institutional history), misi yang diembannya, kultur yang menjadi pegangan dalam bersikap dan berperilaku anggotanya, serta pola penghargaan yang dianut (incentive schemes).

Tiga, kapasitas kelembagaan (institutional capacity). bagian ini perlu telaah bagaimana kemampuan kelembagaan KPH ini dapat mencapai tujuan-tujuannya sendiri. Kemampuan tersebut diukur dari lima aspek, yaitu: strategi kepemimpinan yang dipakai (strategic leadership), perencanaan program (program planning), manajemen dan pelaksanaannya (management and execution), alokasi sumberdaya yang dimiliki (resource allocation), dan hubungan dengan pihak luar yaitu terhadap clients, partners, government policymakers, dan external donors.

Empat, kinerja kelembagaan (institutional performance). Terdapat tiga hal pokok yang harus diperhatikan yaitu keefektifan kelembagaan dalam mencapai tujuantujuannya, efisiensi penggunaan sumber daya, dan keberlanjutan kelembagaan berinteraksi dengan para kelompok kepentingan di luarnya.

Oleh karenanya pemerintah pusat dan provinsi dalam melakukan redesain kelembagaan KPH semsetinya mempertimbangkan empat dimensi tersebut dan tetap membuka ruang kolaborasi yang komperehensif dengan dengan seluruh mitra strategis lainnya termasuk pemerintah kabupaten/kota untuk memastikan keberlanjutan proses pengelolaan yang sudah dijalankan selama ini.

Suporahardjo (2005) mengingatkan bahwa sebaiknya para aktor yang mengusahakan suatu kolaborasi untuk mengantisipasi dan membuat evaluasi atas kemampuannya mengatasi kenyataan dan potensi kendala-kendala yang mungkin dihadapinya. Salah satu kondisi yang menyebabkan tingkat keberhasilannya rendah, yaitu ketika suatu stakeholder mempunyai power untuk melakukan aksi sepihak. Pengelolaan kolaboratif bisa membaik jika para pengambil keputusan memperhatikan aspirasi parapihak yang berkepentingan dengan pelaksanaan program tersebut (Herawati et al. 2010). Dengan demikian untuk menjamin terpenuhinya tujuan pembangunan KPH yang efektif pasca penerapan UU 23 tahun 2014, dibutuhkan formulasi kebijakan yang mampu mendeskripsikan dengan baik situasi dan persoalanpersoalan yang muncul dari pelaksanaan pengelolaan hutan di tingkat tapak, termasuk merumuskan kerangka kolaborasi yang tepat berdasarkan pertimbangan pertimbangan yang telah diuraikan diatas.

\section{Kesimpulan}

Berdasarkan hasil penilaian terhadap 8 kriteria kinerja pembangunan $\mathrm{KPH}$ diwilayah KPHL SWDM, dapat digambarkan bahwa KPH ini memiliki keunikan dibanding dengan $\mathrm{KPH}$ lainnya di indoneisa. Wilayah $\mathrm{KPH}$ yang dikelola berbasis pada tim kolaborasi multipihak menjadi ciri khusus bagi wilayah ini. Meskpun demikian proses pengelolaan yang dijalankan cukup baik dan tidak kalah dengan KPH pada umumnya. Hal ini dapat dilihat dari capaian parameter yang ditetapkan dalam pelaksanaan kajian ini. Namun demikian pasca penerapan UU 23 tahun 2014, terjadi kesimpangsiuran 
pengelolaan yang berimplikasi pada ketidak pastian pengelolaan HLSW-DM. Menyikapi hal tersebut, untuk menjamin optimalisasi dan keberlanjutan pengelolaan ditingkat tapak, dibutuhkan penataan sistem kelembagaan yang berfokus pada empat dimensi utama yaitu penataan kondisi lingkungan eksternal, motivasi kelembagaan, serta kapasitas dan kinerja kelembagaan.

\section{Daftar Pustaka}

Adiwibowo S, Shohibuddin, Kartodihardjo H. 2013. Kontestasi devolusi: ekologi politik pengelolaan hutan berbasis masyarakat. Dalam: Kartodihardjo $\mathrm{H}$. editor. Kembali Ke Jalan Lurus. Kritik Penggunaan IImu dan Praktek Kehutanan Indonesia. Yogyakarta (ID): Nailil Printika.

[BLH] Badan Lingkungan Hidup Balikpapan. 2015. Tata Hutan dan Rencana Pengelolaan Hutan Lindung Sungai Wain dan Sungai Manggar Tahun 20152024. Blikpapan

[FWI] Forest Watch Indonesia. 2014. Panduan penilaian kinerja pembangunan KPH dengan Menggunakan Kriteria dan Indikator FWI 1.0. Bogor: Forest Watch Indonesia.

[FWI] Forest Watch Indonesia. 2014. Potret Keadaan Hutan Indonesia Periode 20092013. Bogor: Forest Watch Indonesia.

[GFI] Governance Forest Initiative Indonesia. 2013. Potret Pelaksanaan Tata Kelola Hutan: Sebuah Studi Mendalam Di Provinsi Kalimantan Tengah dan Nusa Tenggara Barat.Bogor: Forest Watch Indonesia

Herawati, T. et al., 2010. Analisis Respon Pemangku Kepentingan Di Daerah Terhadap Kebijakan Hutan Tanaman Rakyat. Jurnal Analisis Kebijakan Kehutanan. Pusat Penelitian Sosek dan Kebijakan Kehutanan. Bogor, Vol. 7(1), pp.13-25.

Kartodihardjo H, Suwarno E. 2014. Pengarusutamaan Kesatuan Pengelolaan Hutan (KPH) dalam Kebijakan dan Pelaksanaan Perizinan Kehutanan.Jakarta: Direktorat Wilayah Pengelolaan dan Penyiapan Areal Pemanfaatan Kawasan HutanDirektorat Jenderal Planologi Kehutanan.

Mackay, R. and D. Horton. 1998. Assessment of the organizational impacts of the PM\&E project: Assessment and methods. Paper presented at the assessment of organizational impacts of ISNAR's PM\&E project workshop held at the CGIAR secretariat, Washington, D.C., August 4-6, $1998 . \quad$ The Hague: International Service for National Agricultural Research (ISNAR).

[KEPDIRJEN] Keputusan Direktur Jenderal Inventarisasi Dan Tata Guna Hutan No. 12/Kpts/VII-1/1992 Tentang Petunjuk Teknis Pelaksanaan Rekonstruksi Batas Hutan.

[PERDIRJEN] Peraturan Direktur Jenderal Planologi Kehutanan Nomor: P.5/VIIWP3H/2012 Tentang Petunjuk Teknis Tata Hutan Dan Penyusunan Rencana Pengelolaan Hutan Pada Kesatuan Pengelolaan Hutan Lindung (KPHL) Dan Kesatuan Pengelolaan Hutan Produksi (KPHP)

[PERMENDAGRI] Peraturan Menteri Dalam Negeri Nomor 61 Tahun 2010 Tentang Pedoman Organisasi Dan Tata Kerja Kesatuan Pengelolaan Hutan Lindung Dan Kesatuan Pengelolaan Hutan Produksi Di Daerah

[Pemerintah RI] Pemerintah Republik Indonesia. (2014). Undang-Undang No 23 Tahun 2014 Tentang Pemerintahan Daerah

Situmorang, Abdul Wahib (et.al.) 2013. Indeks Tata Kelola Hutan, lahan, dan REDD+ 2012 Di Indonesia. Jakarta : UNDP Indonesia.

Suporahardjo, 2005. Manajemen Kolaborasi, Bogor (ID): Pustaka latin.

Sarjono MA. 2004. Mosaik Sosiologi Kehutanan: Masyarakat Lokal, Politik dan Kelestarian Sumberdaya. Yogyakarta: Debut Press

Wiyono et al. 2006. Kehutanan Multipihak Langkah Menuju Perubahan. Bogor: Center For International Forestry Research. 